This work has been submitted to NECTAR, the Northampton Electronic Collection of Theses and Research.

\title{
Article
}

Title: Postcolonial thresholds: gateways and borders

Creators: Wilson, J. M. and Tunca, D.

DOI: $10.1080 / 17449855.2014 .988434$

Example citation: Wilson, J. M. and Tunca, D. (2015) Postcolonial thresholds: gateways and borders. Journal of Postcolonial Writing. 51(1), pp. 1-6. 1744-9855.

It is advisable to refer to the publisher's version if you intend to cite from this work.

Version: Accepted version

Official URL: http://dx.doi.org/10.1080/17449855.2014.988434

http://nectar.northampton.ac.uk/7252/

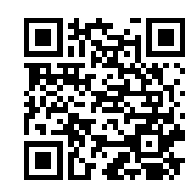




\section{Postcolonial Thresholds: Gateways and borders}

\section{Introduction}

This special issue of the Journal of Postcolonial Writing focuses on concepts of the threshold, a ubiquitous term in postcolonial criticism, which along with cognate labels like the liminal, the interstitial, and the in-between contributes to the redefining of perceptions of space and place that is happening under globalization. "Threshold concepts" (Bugeja 2012, 3 citing Viljoen and van der Merwe, 3, 9) are associated with postcolonialism's theoretical purchase through poststructuralist thought as outlined in the work of critics like Edward Said and Robert Young, and most notably the concepts of third space and cultural hybridity developed by Homi Bhabha. They have been used as a productive counter to the Manichean binaries of periphery and centre, East and West, the global South and North, that recent postcolonial criticism challenges and aims to reconfigure. In current thinking threshold concepts formulate the "middle passage" (Bhabha 1994, 5) or "middle ground" of the postcolonial, where identities can metamorphose or be transformed and power relations negotiated; that is, the place where translation, migrancy, ambivalence and the transnational are reconfigured (Bugeja 2012, 11-13; Viljoen and Merwe 2007, 9).

The threshold or liminal may be defined as a passageway across a boundary, an opening which permits movement from one space to another; in being associated with borders and gateways they comprise, according to Iain Chambers, zones of exchange and transit which signify entry into and exit from existing structures. As Chambers says, in defining a poetics of the interstitial, the liminal, interstitial or threshold introduce a border discourse that is 
"consistently haunted and interpellated by the invisible, by what fails to enter the arena of representation, by what is veiled or falls out of the field of vision of a predictable consensus" (Chamber 2008, 5). Patrolling the border signifies the state's attempt to contain violence, prevent breakdown of order, and police and militarize everyday life (Chambers 5-6). The porousness, incompleteness and arbitrariness of the border underlies the use of the metaphor of being "under construction" which appears in several of the essays found in this issue.

Theorizations of the threshold or liminal in postcolonial studies have pointed to their performativity as a space of activity, and empirical existence as sites of enunciation (Bhabha 1994, 7). But recent critics like Norbert Bugeja in his article in this collection and in his study, Postcolonial Memoir in the Middle East: Rethinking the Liminal in Mashriqui Writing (2012), point to the limits of such repositioning of the middle ground that occurred the 1980s and 1990s. In particular the postcolonial adaptation of the terminology of the liminal /threshold as a place of rite de passage (from the anthropological discourses of Arnold van Gennep and Victor Turner) has been criticized for its lack of definition due to assumptions of unproblematic familiarity and inherent subversiveness (Bugeja 2012; Shome 2003). Bugeja, in particular, has moved away from Bhabha's stress on interstitial third space as one of intervention which offers partial grounding to agency but does not totalize experience (Bhabha 184-185) to the interstitial as a space infiltrated by material processes and power relations between different discourses. The invocation of figurative imagery to reconstruct material reality in terms of liminal space (Shome cited by Bugeja 2012,13) is seen as problematic most notably when considering colonial history and its legacy (Bugeja 12 citing Lazarus 1999). Bugeja, in rethinking the 
contingent spaces of a nation's past in his study of Mashriqui memoirs, for example, questions the adequacy of liminal space as a historical site which ignores the particularities of the colonial encounter that has led to effacement of histories and cultures of marginalized subaltern peoples. Significantly, the first two essays in this volume, those by Norbert Bugeja himself and Asako Nakai, which discuss geopolitical liminality in terms of historicized East-West encounters and conflicts, both note the reinforcement of conservative rather than progressive ideologies, and a dependence on entrenched, institutionalized discourses.

The purchasing power of resistance may also be reduced in interstitial third space, whose double-edged and ambivalent nature undercuts the binaries associated with earlier forms of anti-colonialism; for if the threshold / liminal and interstitial are sites of transgression and crossings-over in which the mediating consciousness plays a part, they are also subject to flux and capable of being destabilized. As Bhabha says "Third space, though unrepresentable [ ... ] constitutes the discursive conditions of enunciation that ensure the meaning and symbols of culture have no primordial or fixity [ ... ] the same signs can be appropriated, translated, rehistoricized and read anew" (37). The fluid and unfixable conditions of the threshold, when positioned between other forms, means it is susceptible to the play of multiple, often contradictory ideologies, discourses and political agendas; it may perpetuate and produce states of partial disablement and empowerment.

The instability of any position adopted in relation to the threshold as performative space - whether confining and conservative or resistant and liberal - is one focus of individual case studies. The essay by Serena Guarracino, for 
example, explicitly identifies the threshold/ liminality with the performance space of the stage and the transformative enactment of the coon by an already black entertainer who blackens up for public display. In Caryl Phillips's novel Dancing in the Dark (2005), Guarracino points out, only partial transformation and intervention can occur in transitional border spaces and there is a risk of occlusion. The theatrical curtain works as a gateway to the black performer's partial acceptance into white society, yet the space of the stage metaphorically becomes a wall, locking him into his performance of "the other" and making him capable of being reabsorbed into that condition of otherness.

The eight essays in this special issue of the Journal of Postcolonial Writing can be read in relation to recent critiques and definitions of the interrelated concepts of the middle ground in their aim to deconstruct binaries, examine the liminal as a performative space, and identify the metaphorical function of gateways, doors and borders. In foregrounding threshold notions they demonstrate the current trend in postcolonial writing and criticism to move away from the resisting strategies and counter-discourses associated with the earlier paradigm of "writing back to empire". They identify instead a more hybridized art, one that exhibits the porous thresholds of intercultural contact and transnational travel, and that appropriates multiple cultural heritages through cross-cultural rewritings, generic crossovers, spatio-temporal expansion of cultural, boundaries, and renegotiations of self / other differences. Through a range of intercultural comparative approaches they reorient the works of writers, photographers and film-makers such as Orhan Pamuk, Nadine Gordimer, Caryl Phillips, Derek Walcott, Chris Abani and Anthony Minghella to show them 
entering and exiting from a variety of places and spaces, outer and inner, public and private, defining and in some senses "postcolonizing" them.

In the opening essay, Norbert Bugeja turns to the temporal structures and subjective determinants of the memoir in his study of Amos Oz's A Tale of Love and Darkness (2003) and Orhan Pamuk's Istanbul: Memories of a City (2005), identifying these as threshold discourses that re-present the problematic urban spaces of Istanbul and Jerusalem/Tel Aviv. The multiple peripheral positionings of both texts, he argues, forge an interaction between the discourses of memory and remembrance, and the representational spaces of national and communal histories. Bugeja explores the threshold between the representation of founding events and the selection of acts of commemoration and subjectivity. Far from being empowering anti-structural signifiers in discourses of resistance and agency, however, the different understandings of threshold/liminality are redeployed through the discourses of autobiography and memoir into the service of quasi-reactionary forms of institutional conservatism.

Asako Nakai focuses on geopolitical and cultural thresholds between East and West, examining English appropriations of the Turkish voice, and identifying in such relationships the ideologically conservative reaction to European 'liberalized' cultural practices. Her subject is the cross-cultural friendship between the Turkish sisters Zeyneb Hamoun and Melek Hamoun, who fled the Ottoman Empire to Europe in 1906, and the English journalist Grace Ellison, who wrote about them and ensured that their works (respectively a memoir and a novel) reached an English audience. The liberating and constraining perspectives of these threshold discourses can be discovered in 
Ellison's disguise as a Turkish woman, wearing the tcharchaff and living in a harem in Istanbul in 1913-14; by contrast Zeyneb Hamoun was critical of western women's freedoms, for example in adopting other cultural identities, yet she herself was subject to Ellison's presence who interfered editorially in her writing, and so was unable to "represent herself and must be represented".

The recent turn towards the spiritual as a porous threshold discourse which filters into and out of other material and metaphysical spaces is the subject of Ileana Dimitriu's essay. Her focus is Nadine Gordimer's post-apartheid novel The Pickup (2001), in which the white settler heroine, dislocated by the profound changes in civil society, undergoes a liminal rite de passage to find a new rootedness and subjecthood. In developing current ideas of "secular spirituality" (i.e. the "subjective expressions of identity and belief") and the "post-religious", Dimitriu draws on critical concepts of spatial liminality in the spiritual as found in myths of sacred spaces as representations of the crossing and negotiation of spiritual and psychological boundaries. Her sacred, spiritual reading of Gordimer's novel refers to the theories of Arnold van Gennep and Victor Turner, of the three-tiered rite de passage to describe the middle stage of “marginality or liminality" (Turner 1988, 25, italics in original) in which class distinctions and prevailing power relations in the social sphere are dissolved. Gordimer's white settler protagonist, Julie, finds in the North African desert a sacred space or axis mundi, and then spiritual rootedness and communitas with the female community of her husband's North African, Muslim family.

Dimitriu introduces the familiar word play on the homophones of routes and roots (also discussed in Wilson, Sandru and Lawson Welsh 2010, 2-4) in defining Gordimer's trajectory from South to North Africa in her embrace of 
secular spiritualism. Sneharika Roy, in considering Derek Walcott's Omeros (1990) and Sashi Tharoor's The Great Indian Novel (1989) as postcolonial rewritings of classical epics, also uses these terms to reconfigure the transitions and tranformations inherent in this transcultural writing with its linguistic and stylistic cross fertilisations and generic hybridity. Walcott's and Tharoor's rewritings, she claims, uproot the epic genre from its mythic past and reroute it into the present through a postmodern globalized spatiality and a "composite" cosmopolitanism. Taking as her theoretical framework Edouard Glissant's concepts of "root identity" and "relation identity", Roy argues that the significance of these polyglot, hybridized genres lies in their shift away from the backward-looking ethnocentrically rooted Dantean, Virgilian and Homeric traditions of western epic. Demonstrating the value of Glissant's relationship philosophy for postcolonial studies in "the valorization of a Ulyssean wandering across cultural borders and thresholds" (i.e. roots in flux, or in rhizomatic relation) postcolonial epics offer instead more Ovidian self-conscious and fluid reinscriptions of national identity. This paradigm shift, Roy concludes, introduces into the walled monuments of the past the "possibilities of metamorphosis and relation identity symbolized by the threshold and the gateway".

Dimitriu stresses that Nadine Gordimer's turn to the spiritual defines her shift from the master narratives associated with the anti-apartheid political struggle to focus on the inner life of the subject in contemporary South Africa. This postcolonial challenge to modernizing agendas and monumental edifices offered by Roy, Dimitriu and Bugeja, also frames the focus on threshold and interstitiality in Natalie Diebschlag's study of Anthony Minghella's film Breaking 
and Entering (2006). Similar tensions between the grand narratives of national life and performative time to those identified in other essays appear in the film's setting in central London against the backdrop of the newly renovated St Pancras International Station, the gateway to Europe and a signature statement of $21^{\text {st }}$ century modernization, and the underclass world of Bosnian refugees. Diebschlag deconstructs the film's cosmopolitanism and uses of urban space, drawing upon the critical framework of Derrida's ethical notion of the "city of refuge", described as a "differential shadow community casting a critical eye on national immigration policies". Monumental and fashionable, St Pancras aims at democratization, the harmonizing of binaries such as rich and poor, national and international, but ultimately it lacks hospitality. Diebschlag contrasts this clinical, architectural structuring of space with the inventive cultural practice of Bosnian refugees, who inhabit threshold metropolitan spaces and whose activities transform London into a more mobile space of play.

Serena Guarracino in her essay, commenting on Caryl Phillips's portrait of the black minstrel Bert Williams who performed on Broadway at the turn of the $20^{\text {th }}$ century, argues that Williams's performances of blackness opened up a "liminal space of possibility" by reiterating and deconstructing socially acceptable practices. As well as highlighting the slipperiness of the interstitial space of the stage, Phillips's novel stresses how the performative act creates and erases the border making this into an inconstant and shifting category. Bénédicte Ledent's essay, in contrast, takes a broader view of Phillips's artistic development by establishing a dialogue between his early plays, Strange Fruit (1981), Where There Is Darkness (1982) and The Shelter (1983), which, she argues, form "the backbone of his world vision", and his "liminal" novel In the 
Falling Snow (2009). Ledent undertakes a "textual archaeology", identifying in the novel preoccupations with problems of interracial relationships that first appear in the plays, pointing out that the threshold figures pervasively in the novel's representations of space (e.g. hallways, stairs, corridors, doorsteps, bridges). Like Roy she stresses the porousness of literary genres and makes the point that in the case of Phillips, the paradigm of writing back to empire has been replaced by a "writing back to oneself", what she calls a "form of autointertextuality". Taken together Guarracino's and Ledent's essays suggest that Phillips is a master of the threshold space, at creating, negotiating, and repositioning the "in-betweenness" of social, political, and domestic biracial relationships to the point of destabilizing the border that defines such interstitial spaces.

Annalisa Oboe, in her study of the South African photographer Pieter Hugo and of "global Igbo" author Chris Abani in Nollywood (2009), also begins with the dialogic transitions between the visual image and the written word between photography and written commentary. Occupying the opposite extreme to Dimitriu's focus on a new secular spirituality, Oboe points to liminality and the threshold here as defining new points of departure and arrival: the transitions between the human and the non-human as found in Nollywood cinema, and the synthesis and realignment of the human figure with the bestial. Noting that Hugo's photos disturb in their attempt to move beyond the acceptable bounds of representation, she states that "the visual and textual works of Hugo and Abani both revisit and remove - through sometimes disquietingly violent aesthetical intervention - the borders that are kept in place by societal control on culture and the arts". 
Finally is the essay "Savors of place: V.S. Naipaul's enigma of departure" by Stanka Radovic, which is included in this special issue for reasons of space. It is not specifically about the threshold and liminality, but can be seen as touching on these concepts in its argument that Naipaul's memories of his Caribbean origins are constantly juxtaposed to his European metropolitan destination. Radovic argues in favour of the subjective evaluation of unlike geographical spheres through the telescope-like lenses of psychology and memory. Trinidad appears monumental and dominates Naipaul's oeuvre because of the central importance to his art of his childhood and youth there: England, as the point of arrival and metropolitan anchoring through the process of writing, is correspondingly reduced to a more liminal space - a threshold across which the older Naipaul constantly interrogates his younger self by contemplating the distanced time and place of his point of departure.

In different ways these essays touch on problems that Bugeja, Viljoen and van der Merwe and others have defined in seeking to explore the protean nature of liminal/threshold discourses in a global age. Some are of consequence for the postcolonial field more generally: the rationale for the transgression and trespass if threshold concepts show a capacity for cultural conservatism and ideological closure, collusion between the project of recovering lost histories and buried narratives if threshold discourses are identified with the recuperative platform of postcolonial studies, and the neo-liberal agenda of the academy; the tension between threshold and institutional discourses in relation to the expansion of the global publishing marketplace; the fluctuation of "threshold agency" between liberation and conservatism, empowerment and 
disenfranchisement. Collectively they contribute to redefinitions of the liminal as a space where a dialectical exchange between different discourses and diverse creative acts can occur. The editors of this issue hope that their study of representations of threshold and the interstitial in texts drawn from a range of media and forms, through the application of diverse theoretical approaches (Jacques Derrida, Henri Lefebvre, Edouard Glissant, Walter Benjamin, and Victor Turner) will contribute to constructing reading practices that can facilitate forms of crossings and transitions between genres, disciplines and temporalities.

Janet Wilson and Daria Tunca.

\section{References}

Bhabha, Homi, K. 1994. The Location of Culture. London: Routledge.

Bugeja, Norbert. 2012. Postcolonial Memoir in the Middle East: Rethinking the Liminal in Mashriqui Writing . London: Routledge.

Chambers Iain. Mediterranean Crossings: The Politics of an Interrupted Modernity. Durham, NC: Duke University Press.

Lazarus, Neil. 1999. Nationalism and Cultural Practice in the Postcolonial World. Cambridge: Cambridge University Press.

Shome, Raka. 2003. "Space Matters. The Power and Practice of Space." Communication Theory 13.1. February: 39-56.

Turner, Victor. 1988. The Anthropology of Performance. New York PAJ Publications.

Viljoen, Hein and Chris van der Merwe, eds. 2007. Beyond the Threshold: Explorations of Liminality and Literature. Newport: Peter Lang. 
Wilson, Janet, Cristina Sandru and Sarah Lawson Welsh. 2010. "Introduction." In Rerouting the Postcolonial: New Directions for the New Millennium, edited by Janet Wilson, Cristina Sandru and Sarah Lawson Welsh. 1-13. London: Routledge. 
